\title{
Estudio comparativo de los áridos reciclados de hormigón y mixtos como material para sub-bases de carreteras
}

\section{A comparative study of recycled aggregates from concrete and mixed debris as material for unbound road sub-base}

\author{
$\underline{\text { J. R. Jiménez }}{ }^{(*)}$, F. Agrela(*), J. Ayuso(*), M. López ${ }^{(*)}$
}

Recepción/Received: 28-VII-09

Aceptación/Accepted: 14-VI-10

Publicado online/Online publishing: 30-VI-10

RESUMEN

Siete áridos reciclados de residuos de construcción y demolición (RCD) se han evaluado como zahorras para la construcción de sub-bases de carreteras. Los resultados muestran que los áridos reciclados de hormigón cumplen todas las especificaciones del Pliego de Prescripciones Técnicas Generales para Obras de Carreteras de España (PG-3) para su uso en capas estructurales (sub-base) de las categorías de tráfico T3 y T4. Algunos áridos reciclados mixtos no cumplen por escaso margen algunas de las especificaciones, debido a un alto contenido de compuestos de azufre y a una menor resistencia a la fragmentación. El precribado de la fracción fina antes de la trituración de los RCD mixtos reduce el contenido de azufre total y mejora la calidad, por el contrario, el precribado de los RCD de hormigón no tiene ningún efecto sobre la calidad de los áridos reciclados. Los resultados se compararon con una zahorra artificial caliza como árido natural.

Palabras clave: construcción, demolición, árido reciclado, residuos, sub-base.
SUMMARY

Seven different types of recycled aggregates from construction and demolition waste (CDW) have been evaluated as granular materials for unbound road subbases construction. The results showed that recycled concrete aggregates complied with all specifications for using in the construction of unbound structural layers (sub-base) for T3 and T4 traffic categories according to the Spanish General Technical Specification for Road Construction (PG-3). Some mixed recycled aggregates fell short of some specifications due to a high content of sulphur compounds and poor fragmentation resistance. Sieving off the fine fraction prior to crushing the mixed CDW reduce the total sulphur content and improve the quality of the mixed recycled aggregates, by contrast, pre-sieving concrete CDW had no effect on the quality of the resulting aggregates. The results were compared with a crushed limestone as natural aggregate.

Keywords: construction, demolition, recycled aggregate, waste, sub-base.

(*) Universidad de Córdoba (Córdoba, España). 


\section{INTRODUCCIÓN}

El auge de la industria de la construcción en España durante la última década ha aumentado considerablemente la producción de Residuos de Construcción y Demolición (RCD), agravando el problema ambiental que se deriva de una gestión inadecuada, como es su vertido incontrolado.

De acuerdo con el Gremio Español de Entidades de Reciclaje de residuos de demolición, España produjo un total 37,5 millones de toneladas de RCD en el año 2006, 15 millones de los cuales (40\%) fueron adecuadamente procesados en las plantas de tratamiento de RCD, y los restantes 22,5 millones se dispusieron en vertederos. La producción de áridos reciclados fue de 5 millones (13,3\% de tasa de reciclado). Sin embargo, la caída del sector de la construcción en España, más del $50 \%$ en los últimos dos años debido a la crisis económica ha producido una reducción considerable en la producción de RCD.

Entre las razones por las que no se alcanza una mayor tasa de reciclado, se pueden citar, el que su depósito en vertedero sin tratamiento previo tiene un coste muy bajo, los altos costes de transporte y tratamiento de los residuos, el bajo valor de los áridos reciclados y la falta de conciencia ambiental. Desde un punto de vista puramente económico el reciclaje de RCD solo es atractivo cuando el producto reciclado es competitivo con los recursos naturales en relación a su coste y calidad. Los materiales reciclados normalmente serán competitivos donde haya escasez de materias primas y lugares adecuados de depósito (1).

De conformidad con la Directiva marco 2006/12/CE relativa a los residuos, el Ministerio de Medio Ambiente de España (MMA) aprobó el Plan Nacional Integral de Residuos (PNIR) 2008-2015 (2). Los objetivos fijados en el PNIR para los RCD es que el $100 \%$ de todos los materiales peligrosos contenidos en los RCD deben ser gestionados ambientalmente de manera correcta en 2010. Asimismo, se establece un objetivo de reciclado del $25 \%$ para 2012 y del $35 \%$ para 2015. Para otras operaciones de recuperación, incluido el relleno, el objetivo es del $15 \%$ y $20 \%$ respectivamente.

Por otra parte, en los últimos años, el gobierno español también ha publicado algunas normas sobre el uso de áridos reciclados. Una de ellas es la Orden/FOM/891/2004 del Ministerio de Obras Públicas, que modificó el Pliego de Prescripciones Técnicas Generales para Obras de Carreteras (PG-3) a fin de permitir el uso de áridos reciclados como material granular en capas estructurales (3). Asimis$\mathrm{mo}$, en base al trabajo de investigación realizado por el Grupo GT 2/5 (4), la nueva Instrucción Española de Hormigón Estructural (EHE-2008) permite el uso de áridos reciclados gruesos para obtener hormigón estructural (5).

\section{INTRODUCTION}

The rise of the construction industry in Spain over the past decade has substantially increased the production of Construction and Demolition Waste (CDW), thus worsening the environmental problems arising from its inadequate management, as is their uncontrolled landfill.

According to the Spanish Guild of Demolition Waste Recycling Entities, Spain produced an overall 37.5 million tons of CDW in 2006, 15 million of which (40\%) was properly processed at CDW treatment plants, and the remaining 22.5 million were placed in landfill sites. The production of recycled aggregates was 5 million (13.3\% recycling rate). Nevertheless, the fall of the construction sector in Spain, over 50\% in the last two years because of the economic crisis has produced a considerable reduction in the production of $C D W$.

The reasons precluding more extensive recycling include the very low cost of dumping CDW in landfills, the high transportation and processing costs of the waste, the low value of recycled aggregates and the lack of environmental concern. From a purely economic point of view the recycling of CDW is only attractive when the recycled product is competitive with natural resources in relation to cost and quality. Recycled materials will normally be competitive where there is a shortage of both raw materials and suitable deposit sites (1).

Pursuant to Framework Directive 2006/12/EC on waste, Spain's Ministry of Environment (MoE) approved the National Integral Plan for Waste (PNIR) 2008-2015 (2). The objectives set in PNIR for CDW are that $100 \%$ of all hazardous materials contained in CDW should be properly environmentally managed by 2010. Also, it set a target recycling rate of $25 \%$ for 2012 and one of $35 \%$ for 2015. For other recovery operations including filling target is $15 \%$ and $20 \%$ respectively.

On the other hand, in recent years, the Spanish government has also issued some regulations on the use of recycled aggregates. One is Order/FOM/891/2004 of the Ministry of Public Works, which amended the Spanish General Technical Specification for Road Construction PG-3 in order to allow the use of recycled aggregates as materials for road granular structural layers (3). Likewise, based on the research work done by the Group GT 2/5 (4), the new Spanish Structural Concrete Code (EHE-2008) allows the use of coarse recycled aggregates to obtain structural concrete (5). 
Un nuevo Real Decreto (RD) regula la producción y gestión de RCD en España, que prohíbe el depósito de residuos no tratados en vertederos a fin de impulsar el reciclado y la valorización de la mayoría de los materiales que llegan a las plantas de tratamiento (6). Con el fin de cumplir las metas establecidas en el RD, se ha implementado en España un modelo de cuantificación de residuos (7).

La producción estimada de RCD en la provincia de Córdoba (sur de España) en 2007 fue de 725.909 toneladas. Las nueve plantas de reciclaje de RCD de la provincia, que incluyen seis fijas y tres plantas móviles, recibieron un total de 202.955 toneladas en ese año. Dado que esta cifra representa el $28 \%$ de la producción estimada de RCD en Córdoba, el resto (72\%) debe haber sido depositado en vertederos incontrolados. La producción de áridos reciclados ascendió a 167.581 toneladas, que representa el $23,1 \%$ de la producción total de residuos. La mayor parte de los áridos reciclados se utilizaron como materiales para la construcción de explanadas de caminos rurales, con menos requisitos normativos (8).

En este trabajo, se ha estudiado la viabilidad de utilizar áridos reciclados procedentes de hormigón y mixtos obtenidos con tres procesos diferentes de reciclado como material de sub-base. Los resultados se han analizado y comparado con un árido natural típico utilizado en la construcción de capas estructurales no ligadas (subbases). Este estudio es muy importante, ya que, si los resultados son aceptables, los áridos reciclados de hormigón y mixtos obtendrían un valor añadido, se incrementarían las ventas y en consecuencia la tasa de reciclaje en España. Esto permitiría prolongar la vida útil de los vertederos y reducir las necesidades de recursos primarios (minerales y energía), reduciendo el impacto ambiental de la búsqueda y apertura de nuevas canteras.

El potencial de los áridos reciclados procedentes de RCD como materiales para la construcción de explanadas y capas estructurales ha sido estudiado previamente. Los áridos reciclados procedentes de residuos de hormigón y mixtos se clasifican como suelos tolerables (Art. 330 PG-3) aptos para la construcción de terraplenes. Estos materiales tienen una gran capacidad de soporte medida por el ensayo CBR. Las principales propiedades limitantes son el contenido de sales solubles y de yeso (9-12).

Vegas y col. (12) indican que las propiedades más críticas de los áridos reciclados de RCD para su uso como material granular en capas estructurales son el contenido de azufre y la resistencia a la fragmentación. Poon y Chan (13) han estudiado el uso de áridos reciclados que contienen proporciones variables de partículas de hormigón y de ladrillos triturados como materiales para subbase de carreteras y han obtenido valores aceptables de CBR después de inundación; encontraron que la única
A new national decree regulates the production and management of CDW in Spain, banned landfill dumping of untreated waste in order to boost recycling and the valorisation of most of the materials reaching processing plants (6). In order to meet the goals established in the decree, a waste quantification model has been implemented in Spain (7).

The estimated production of CDW for the province of Córdoba (southern Spain) in 2007 was 725909 tons. The nine CDW recycling plants in the province, which included six centralized and three mobile plants, received a total of 202955 tons that year. Since this figure accounts for $28 \%$ of the estimated production of CDW in Cordoba, the remainder (72\%) must have been dumped in uncontrolled landfills. The production of recycled aggregates amounted to 167581 tons, which accounts $23.1 \%$ of the total production of waste. The most recycled aggregates were used to as materials for roadbed in rural road constructions, with fewer regulatory requirements ( 8 ).

In this paper, the feasibility of using recycled aggregates from concrete and mixed debris with three different recycling processes as subbase materials was studied. The results were analyzed and compared with a typical natural aggregates used in the construction of structural unbound layers (sub-bases). This study is very important since, should the results be acceptable, recycled aggregates from concrete and mixed debris could be given an added value, increase sales opportunities and consequently the recycling rate in Spain, in order to prolong the life of landfill sites and reduce the primary resource requirement (mineral and energy), reducing the environmental impact of searching for and opening new quarries.

The potential of CDW recycled aggregates as materials for roadbeds and structural layers has been previously studied. The recycled aggregates from concrete and mixed debris is classified as tolerable soils (Art 330 PG-3) being suitable for the construction of roadbeds. These materials have a high bearing capacity as measured by the CBR test. The main limiting properties are the content of soluble salts and gypsum (9-12).

Vegas et al. (12) found that the most critical properties of recycled aggregates from CDW for its use as granular material in structural unbound layers are sulphur compounds and the fragmentation resistance. Poon and Chan (13) examined the use of mixed recycled aggregates containing variable proportions of recycled concrete and crushed clay brick as road sub-base materials and obtained acceptable CBR values for soaked specimens; they found the only disadvantage of the 
desventaja de estos áridos es que se desintegran por completo durante el ensayo de estabilidad de volumen, lo que atribuyeron a la gran cantidad de mortero adherido. Arm (14) indica que la rigidez de una capa de subbase de árido reciclado de hormigón aumenta con el tiempo debido a las propiedades auto-cementantes que posee este material.

\section{MATERIALES Y MÉTODOS}

\subsection{Materiales}

Se han estudiado siete áridos reciclados de $R C D$, tres áridos reciclados de hormigón (RCA-1 a RCA-3) y cuatro áridos reciclados mixtos (MD-1 a MD-4). Para cada material, se tomó una muestra de alrededor de $500 \mathrm{~kg}$ de los acopios de tres plantas con proceso de reciclaje diferente en Córdoba (España). Como árido natural de control se ha usado una zahorra artificial caliza.

Los áridos RCA-1 y MD-1 se obtuvieron de la primera planta de reciclaje, donde los escombros de hormigón y mixtos se precribaron para eliminar la fracción 0 / 20 $\mathrm{mm}$, que es rechazada. La fracción gruesa (> $20 \mathrm{~mm}$ ) fue triturada en un molino de impacto. Se utilizó una criba vibrante para separar los áridos reciclados 0/40 mm de los áridos de tamaño superior a $40 \mathrm{~mm}$, que son retornados al alimentador del molino.

Los áridos RCA-2, RCA-3 y MD-4 se obtuvieron de la segunda planta de reciclaje, donde los RCD fueron triturados en un molino de impacto y separados con cribas vibrantes. A diferencia de la primera planta, los residuos de hormigón y los mixtos no se precribaron para eliminar la fracción fina antes de la trituración.

Los áridos MD-2 y MD-3 se obtuvieron de la tercera planta de reciclaje, donde los RCD se precribaron para eliminar la fracción 0 / $10 \mathrm{~mm}$, que es rechazada. La fracción retenida (> $10 \mathrm{~mm}$ ) fue procesada como en la primera planta.

\subsection{Composición de los áridos reciclados}

Los RCD están compuestos por diferentes materiales: asfalto, cerámica, hormigón y mortero, áridos naturales, yeso e impurezas (madera, vidrio, plástico, metal). El hormigón y el mortero está compuesto por áridos naturales con mortero de cemento adherido.

Todas las plantas realizan a los RCD una separación manual de grandes impurezas antes de la trituración, y los molinos de impacto están equipados con separadores magnéticos para retirar los elementos metálicos pequeños. resulting aggregates to be that they disintegrated completely during the soundness test, which they ascribed to the large amounts of mortar attached. Arm (14) found the stiffness of a sub-base layer consisting of recycled concrete aggregate to increase with time due to the material possessing self-cementing properties.

\section{MATERIALS AND METHODS}

\subsection{Materials}

The materials studied were seven recycled aggregates from $C D W$; three recycled aggregates from concrete (RCA-1 to $R C A-3)$ and the other four were from mixed debris (MD-1 to MD-4). For each material, a sample of about $500 \mathrm{~kg}$ was obtained from the stockpiles of three recycling plants in Córdoba (Spain) with different recycling process. Crushed limestone was used as the natural aggregate control in this study.

Aggregates RCA-1 and MD-1 were obtained from the first recycling plant, where concrete and mixed debris were pre-screening to remove the $0 / 20 \mathrm{~mm}$ fraction, which is rejected. The coarse fraction (> $20 \mathrm{~mm}$ ) was crushed in an impact crusher and separating with vibrating screens to separate recycled aggregates $0 / 40 \mathrm{~mm}$ in size from larger aggregates, which are returned to the impact crusher feeder.

Aggregates RCA-2, RCA-3 and MD-4 were collected from the second recycling plant, where CDW was crushed in an impact crusher and separating with vibrating screens. Unlike the first plant, concrete waste and mixed debris was not pre-screened to remove the fine fraction prior to crushing.

Aggregates MD-2 and MD-3 were obtained from the third recycling plant, where $C D W$ were pre-screening to remove the $0 / 10 \mathrm{~mm}$ fraction, which is rejected. The retained fraction (>10 $\mathrm{mm}$ ) was processed like the first plant.

\subsection{Recycled aggregates composition}

CDW are composed by different materials: asphalt, ceramic, concrete \& mortar, natural aggregates, gypsum and impurities (wood, glass, plastic, metal). Concrete \& mortar is composed by natural aggregates whit cement mortar attached.

All plants subject CDW to manual separator of big impurities prior to crushing, and their impact crusher are equipped with magnetic separators to removed small metallic elements. 
Los siete áridos reciclados se caracterizaron para identificar y cuantificar los componentes de la fracción gruesa según la norma UNE-EN 933-11:2009. La Tabla 1 muestra la composición de la fracción 8 / 40 mm.
The seven recycled aggregates were characterized by identifying and quantifying the components in the coarse fraction according to the UNE-EN 933-11-2009 standard. Table 1 shows the composition of the $8 / 40 \mathrm{~mm}$ fraction.

Tabla 1 / Table 1

Composición de los áridos reciclados.

Composition of recycled aggregates.

\begin{tabular}{|c|c|c|c|c|c|c|c|c|}
\hline \multirow{3}{*}{$\begin{array}{l}\text { Clase I } \\
\text { Class }\end{array}$} & \multirow{3}{*}{ Tipo / Type } & \multicolumn{7}{|c|}{ Peso / Weight (\%) } \\
\hline & & \multicolumn{3}{|c|}{$\begin{array}{l}\text { Áridos reciclados de hormigón / } \\
\text { Recycled concrete aggregate }\end{array}$} & \multicolumn{4}{|c|}{ Áridos reciclados mixtos / Recycled mixed debris aggregate } \\
\hline & & RCA-1 & RCA-2 & RCA-3 & MD-1 & MD-2 & MD-3 & MD-4 \\
\hline A & Asfalto / Asphalt & 0.0 & 0.1 & 0.3 & 4.4 & 0.8 & 2.9 & 9.2 \\
\hline B & Cerámico / Ceramic & 3.1 & 1.6 & 3.5 & 26.6 & 19.0 & 21.0 & 21.0 \\
\hline C & $\begin{array}{l}\text { Hormigón y mortero/ } \\
\text { Concrete \& mortar (a) }\end{array}$ & 76.0 & 74.6 & 71.6 & 34.8 & 37.5 & 50.9 & 15.2 \\
\hline L & $\begin{array}{l}\text { Partículas ligeras / } \\
\text { Lightweight particles }\end{array}$ & 0.0 & 0.0 & 0.0 & 0.0 & 0.1 & 0.1 & 0.0 \\
\hline U & $\begin{array}{l}\text { Árido natural / Natural } \\
\text { aggregate (b) }\end{array}$ & 20.8 & 23.6 & 24.6 & 33.4 & 41.4 & 22.0 & 52.7 \\
\hline $\mathrm{X} 1$ & Tierra / Natural ground & 0.0 & 0.0 & 0.0 & 0.2 & 0.2 & 2.1 & 0.3 \\
\hline $\mathrm{X} 2$ & Otros / Other (c) & 0.0 & 0.0 & 0.0 & 0.1 & 0.1 & 0.1 & 0.1 \\
\hline \multirow[t]{2}{*}{$\mathrm{X} 3$} & Yeso / Gypsum & 0.1 & 0.1 & 0.0 & 0.4 & 0.9 & 1.0 & 1.5 \\
\hline & Total / Total & 100 & 100 & 100 & 100 & 100 & 100 & 100 \\
\hline
\end{tabular}

(a) Árido natural con mortero adherido. / Natural aggregates with cement mortar attached.

(b) Árido natural sin mortero adherido. / Natural aggregates without cement mortar attached.

(c) Madera, vidrio, plástico, metales. / Wood, glass, plastic, metals.

Los tres áridos reciclados de hormigón (RCA) se consideran muy puros, ya que más del $96 \%$ de las partículas son de hormigón; 71 a $76 \%$ de áridos naturales con mortero de cemento adherido y 20 a $25 \%$ de árido natural sin mortero de cemento adherido. Los componentes restantes deben ser considerados como impurezas y son muy bajos, del 1,6 al 3,5\% es material cerámico, del 0 al $0,3 \%$ asfalto, del 0 al $0,1 \%$ de yeso, y cantidades despreciables de madera, vidrio, plástico, metal, suelo natural y partículas ligeras. La presencia de impurezas es normal en los áridos reciclados procedentes de una planta de reciclaje fija (15), aunque el bajo porcentaje de estos componentes es debido a que los residuos de hormigón se procesan por separado de los mixtos.

La composición de los áridos reciclados mixtos (MD) es más variable que la de los RCA. Así, el porcentaje de áridos naturales con mortero de cemento adherido (hormigón y mortero) varía entre un $15-51 \%$, el árido natural sin mortero de cemento adherido entre el 22-53\%, y entre el $21-27 \%$ los materiales cerámicos. En los MD, los materiales cerámicos (ladrillos, azulejos) no deben ser considerados impurezas. Su contenido en impurezas es superior a los RCA, con $0,4-1,5 \%$ de yeso, $0,9-9,2 \%$ de asfalto, $0,2-2,1 \%$ de tierra natural, y menos del $0,1 \%$ de madera, vidrio, plástico, metal y partículas ligeras.
The three recycled concrete aggregates (RCA) were considered very pure, since more than $96 \%$ was consisted of concrete; 71 to $76 \%$ natural aggregates with cement mortar attached and 20 to $25 \%$ natural aggregate without cement mortar attached. The remaining components should be considered as impurities and were very low; 1.6 to $3.5 \%$ was ceramic material, 0 to $0.3 \%$ was asphalt, 0 to $0.1 \%$ was gypsum, and negligible amount of wood, glass, plastic, metal, natural ground and lightweight particles. The presence of impurities is normal in recycled aggregate collected from a centralized recycling plant (15), though the low percent of theses components are due to concrete waste are processed separately from mixed debris.

The composition of recycled mixed debris aggregates (MD) is more variable than RCA. Thus, the percentage of natural aggregates with cement mortar attached (concrete \& mortar) ranges from 15-51\%, 22-53\% natural aggregate without cement mortar attached and $21-27 \%$ ceramic materials. In MD the ceramic materials (brick, glazed wall tile) should not be considered impurities. Their contents in undesirable materials were higher than those in RCA, with $0.4-1.5 \%$ gypsum, $0.9-9.2 \%$ asphalt, 0.2$2.1 \%$ natural ground and less than $0.1 \%$ wood, glass, plastic, metal and lightweight particles in combination. 


\subsection{Ensayos de laboratorio}

Los ensayos realizados siguen las recomendaciones del artículo 510 del Pliego de Prescripciones Técnicas Generales para Obras de Carreteras de España (PG-3), que establece los requisitos de los materiales no ligados para su uso en capas estructurales (sub-bases). Los materiales han sido ensayados de acuerdo con las normas especificadas en la Tabla 4. Cada valor obtenido en este trabajo es un promedio de dos mediciones.

\section{RESULTADOS}

\subsection{Granulometría}

Para que los áridos reciclados (RA) se puedan emplear como material granular en sub-bases de carreteras, su granulometría (PSD) debe estar comprendida en alguno de los husos granulométricos fijados por el Art. 510 del PG-3, y que se designan como ZA25 y ZA20.

La Tabla 2 muestra los resultados de los siete áridos reciclados y el árido natural de control, así como los husos granulométricos de la ZA25 y ZA20, respectivamente. Como se puede ver, la granulometría (PSD) para los áridos RCA-1 a RCA-3 y MD-1 a MD-3 está dentro del huso granulométrico de la ZA25, mientras que el MD-4 y NA están dentro del huso granulométrico de la ZA20 debido a su mayor contenido en partículas finas.

\subsection{Laboratory Test}

The batch of tests follows the recommendations of Article 510 of the Spanish General Technical Specifications for Road Construction (PG-3), which establishes prescriptions of the materials for using in unbound structural layers (sub-bases). Materials were tested according with the standards specified in table 4. Each value presented in this paper is an average of two measurements.

\section{RESULTADOS}

\subsection{Particle size distribution}

For recycled aggregates (RA) to be useful as granular material for road sub-bases, their particle size distribution (PSD) must fall within the grading envelopes set in Article 510 of the PG-3 specification (3), which are designated GE25 or GE20.

Table 2, show the results for the seven recycled aggregates and the control natural aggregate and the grading envelope GE25 and GE20, respectively. As can be seen, the PSD for RCA-1 to RCA-3 and MD-1 to MD-3 fell within the grading envelope for GE25, whereas that for MD-4 and NA fell within the envelope for GE20 owing to its excessive fine grained content.

Tabla 2 / Table 2

Granulometría de los áridos ensayados y husos granulométricos ZA25 y ZA20 del PG-3.

Particle size distribution of aggregates tested and grading envelopes GA25 and GA20 set in PG-3.

\begin{tabular}{|c|c|c|c|c|c|c|c|c|c|}
\hline & \multicolumn{9}{|c|}{ Granulometría $(\mathrm{mm})$ / Particle size distribution $(\mathrm{mm})$} \\
\hline & 40 & 25 & 20 & 8 & 4 & 2 & 0.500 & 0.250 & 0.063 \\
\hline & \multicolumn{9}{|c|}{ Porcentaje que pasa $(\%)$ / Percent passing $(\%)$} \\
\hline ZA25/GE25 & 100 & $75-100$ & $65-90$ & $40-63$ & $26-45$ & $15-32$ & $7-21$ & 4-16 & $0-9$ \\
\hline ZA20/GE20 & - & 100 & $75-100$ & $45-73$ & $31-54$ & $20-40$ & $9-24$ & $5-18$ & $0-9$ \\
\hline NA & 100 & 96.3 & 91.3 & 65.3 & 47.3 & 35.3 & 17.7 & 12.3 & 7.3 \\
\hline RCA-1 & 100 & 92.3 & 85.7 & 56.0 & 39.7 & 30.0 & 15.6 & 10.7 & 5.4 \\
\hline RCA-2 & 100 & 88.0 & 80.1 & 52.0 & 35.9 & 26.1 & 12.0 & 8.0 & 4.1 \\
\hline RCA-3 & 100 & 75.2 & 67.1 & 46.8 & 31.3 & 23.7 & 14.7 & 11.5 & 7.7 \\
\hline MD-1 & 100 & 84.4 & 74.1 & 46.1 & 34.6 & 28.8 & 19.9 & 16.7 & 9.5 \\
\hline MD-2 & 100 & 86.0 & 76.9 & 45.0 & 31.3 & 24.0 & 12.6 & 8.7 & 4.1 \\
\hline MD-3 & 100 & 86.2 & 77.0 & 47.2 & 34.2 & 27.4 & 17.4 & 13.3 & 7.6 \\
\hline MD-4 & 100 & 94.0 & 92.01 & 66.8 & 49.1 & 40.0 & 25.0 & 18.9 & 3.1 \\
\hline
\end{tabular}

Otra condición que deben cumplir los áridos es que el cernido por el tamiz 0,063 mm de la UNE-EN 933-2:1996 sea menor que los dos tercios del cernido por el tamiz $0,250 \mathrm{~mm}$ de la misma norma. Todos los áridos reciclados y el natural cumplen esta condición.

En este trabajo se ha realizado un estudio estadístico de las granulometrías. Para describir la granulometría de los
One other condition to be fulfilled by aggregates is that the fraction passing through the $0.063 \mathrm{~mm}$ sieve in UNE-EN 933-2:1996 should be less than two-thirds the fraction passing through the $0.250 \mathrm{~mm}$ sieve in the same standard. All recycled and natural aggregates fulfilled this condition.

The particle size distributions are processed statistically in this work. The 2-Parameter Weibull distribution (16) is 
áridos reciclados triturados se ha usado la distribución de Weibull de 2-Parámetros. La función de la distribución de Weibull acumulada para 2-Parámetros es [1] used to describe the particle size distribution of $R A$ generated by crushing operations. The cumulative distribution function for the 2-Parameter Weibull is [1]

$$
P(D ; \lambda, k)=1-\exp \left[-\left(\frac{D}{\lambda}\right)^{k}\right]
$$

donde $P(D ; \lambda, k)$ es el porcentaje de masa de partículas con un diámetro $<D ; \lambda$ es el tamaño medio de partícula y $k$ es una medida de la dispersión del tamaño de partículas. La Tabla 3 muestra los parámetros de calibración y los valores de $R^{2}$. El valor de $R^{2} \geq 0,95$ muestra que la distribución Weibull de 2-Parámetros seleccionada y sus parámetros asociados son buenos. where $P(D ; \lambda, k)$ is the mass fraction of particles with diameter $\langle D ; \lambda$ is the mean particle size and $k$ is the measure of particle size spread. Table 3 lists the calibrated parameters and the values of $R^{2}$. The $R^{2}$ $\geq 0.95$ shows that the 2-Parameter Weibull distributions selected and its associated parameters are good.

Tabla 3 / Table 3

Bondad del ajuste de la distribución de Weibull mediante $\mathrm{R}^{2}$. Goodness-of-fit test for the Weibull probability distributions using $R^{2}$.

\begin{tabular}{|c|c|c|c|}
\hline Árido / Aggregate & $\boldsymbol{\lambda}$ & $\mathbf{K}$ & $\mathbf{R}^{\mathbf{2}}$ \\
\hline NA & 6.5200 & 0.70758 & 0.99298 \\
\hline RCA-1 & 8.6648 & 0.74390 & 0.98961 \\
\hline RCA-2 & 10.383 & 0.78401 & 0.99256 \\
\hline RCA-3 & 11.332 & 0.66231 & 0.94557 \\
\hline MD-1 & 11.382 & 0.69917 & 0.95295 \\
\hline MD-2 & 12.010 & 0.82049 & 0.98398 \\
\hline MD-3 & 11.146 & 0.70654 & 0.97034 \\
\hline MD-4 & 9.8570 & 0.61215 & 0.98570 \\
\hline
\end{tabular}

La Figura 1 muestra la relación entre el coeficiente de Los Ángeles de los áridos ensayados y el valor de $\lambda$ de la distribución de Weibull, cuanto mayor es el coeficiente de Los Ángeles mayor es el tamaño medio de las partículas.
Figure 1 shows the relationship between Los Angeles coefficient of the aggregates tested and the $\lambda$ value in the Weibull distribution, the higher Los Angeles coefficient, the higher mean particle size is.

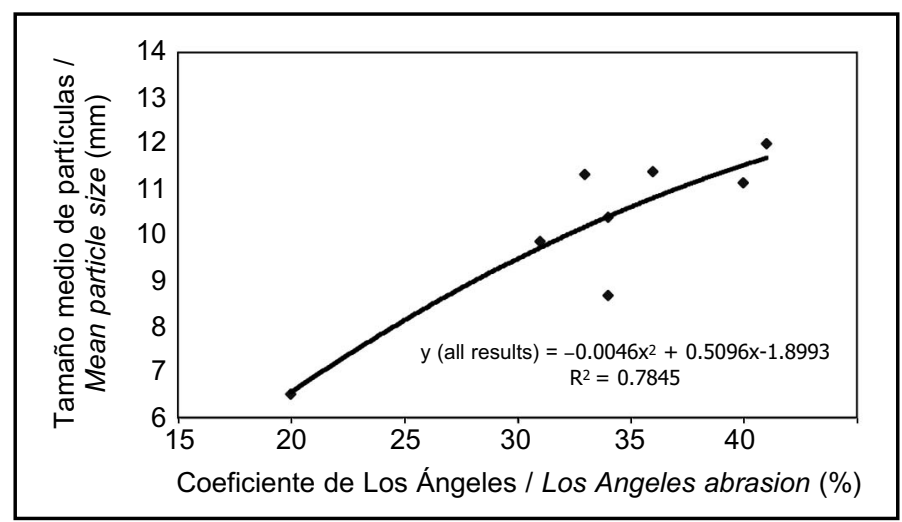

Figura 1. Relación entre el coeficiente de Los Ángeles y el parámetro de la distribución de Weibull (tamaño medio de las partículas). Figure 1. Relationship between Los Angeles abrasion and the parameter in the Weibull distribution (mean particle size).

\subsection{Caracterización como material para sub-bases de carreteras}

La Tabla 4 muestra los resultados de todos los ensayos y los límites establecidos por la Norma (Art. 510 del PG-3) para categorías de tráfico T3 y T4 (menos de 200

\subsection{Characterization as materials for unbound road sub-base}

Table 4 shows the results of all tests and the limits established by standard (Art. 510 in PG-3) for traffic categories T3 and T4 (less than 200 heavy vehicles / day). 
vehículos pesados / día). El árido natural ensayado como control cumple estos límites.
The NA tested as control aggregate fulfills this limits.

Tabla 4 / Table 4

Caracterización.

Characterization.

\begin{tabular}{|c|c|c|c|c|c|c|c|c|c|}
\hline \multirow{2}{*}{ Parámetros / Parameter } & \multicolumn{8}{|c|}{ Resultados / Results } & \multirow{2}{*}{$\begin{array}{l}\text { Límites establecidos por la } \\
\text { Norma / Limits established } \\
\text { by Standard }\end{array}$} \\
\hline & NA & RCA-1 & RCA-2 & RCA-3 & MD-1 & MD-2 & MD-3 & MD-4 & \\
\hline $\begin{array}{l}\text { Plasticidad / Plasticity (UNE } 103103: 1994 \text { \& } \\
\text { UNE } 103104: 1993)\end{array}$ & NP & NP & NP & NP & NP & NP & NP & NP & No Plástico / Non plastic (NP) \\
\hline $\begin{array}{l}\text { Coeficiente de limpieza / Clean coefficient } \\
\text { (UNE } 146130: 2000)\end{array}$ & 0.86 & 0.34 & 0.28 & 0.3 & 0.84 & 1.9 & 1.53 & 3.7 & $<2 \%$ \\
\hline $\begin{array}{l}\text { Equivalente de arena / Sand equivalent } \\
\text { (UNE EN 933-8:2000) }\end{array}$ & 41 & 51 & 62 & 50 & 39 & 44 & 58 & 35 & $\mathrm{~T} 3$ to T4: SE > 35 \\
\hline $\begin{array}{l}\text { Coeficiente de Los Ángeles / Los Angeles } \\
\text { loss (UNE EN 1097-2:1999) }\end{array}$ & 20 & 34 & 34 & 33 & 36 & 41 & 40 & 31 & T3 to T4: $<35 \%$ \\
\hline $\begin{array}{l}\text { Índice de Lajas / Form coefficient } \\
\text { (UNE EN 933-3:1997) }\end{array}$ & 8 & 8.5 & 7.5 & 6.4 & 19 & 17 & 16 & 12 & $<35 \%$ \\
\hline $\begin{array}{l}\text { Partículas trituradas / Crushed particles } \\
\text { (UNE EN 933-5:1999) }\end{array}$ & $96 \%$ & $70 \%$ & $73 \%$ & $78 \%$ & $70 \%$ & $69 \%$ & $94 \%$ & $69 \%$ & $\mathrm{~T} 3$ to $\mathrm{T} 4:>50 \%$ \\
\hline $\begin{array}{l}\text { Compuestos de azufre totales / Total } \\
\text { sulphur content (UNE EN 1744-1:1999) }\end{array}$ & $<0.01$ & 0.6 & 0.8 & 0.8 & 1.0 & 1.3 & 1.4 & 6.0 & $\begin{array}{l}<0.5 \%(a) \\
<1 \%(b)\end{array}$ \\
\hline CBR (UNE 103502:1995) & $152 \%$ & $138 \%$ & $97 \%$ & $109 \%$ & $68 \%$ & $71 \%$ & $94 \%$ & $62 \%$ & $>20 \%$ \\
\hline $\begin{array}{l}\text { Hinchamientos tras } 4 \text { días de inundación / } \\
\text { Swelling after } 4 \text { day's soaking } \\
\text { (UNE 103502:1995) }\end{array}$ & $0,03 \%$ & $0.01 \%$ & $0.03 \%$ & $0.00 \%$ & $0.05 \%$ & $0.06 \%$ & $0.00 \%$ & $0.01 \%$ & $<5 \%$ \\
\hline
\end{tabular}

(a) Para materiales en contacto con capas tratadas con cemento. / For materials in contact with cement treated layers.

(b) En los demás casos. / In other cases.

De acuerdo con otras experiencias (9-12), los áridos reciclados estudiados son no plásticos, y su coeficiente de forma, partículas trituradas y equivalente de arena cumplen los límites establecidos por la norma. El coeficiente de forma en los RCA y NA es similar y más pequeño que en los MD.

El coeficiente de limpieza no es una propiedad crítica; todos los áridos reciclados cumplen los límites establecidos por la norma (Art. 510 del PG-3), excepto el MD-4, esto puede ser debido al mayor porcentaje de partículas finas.

El coeficiente de Los Ángeles depende principalmente de la abrasión sufrida por los áridos naturales, el hormigón y los materiales cerámicos. Estudios recientes han puesto de manifiesto que en el ensayo de Los Ángeles todo el mortero adherido de los áridos reciclados de hormigón se pulveriza (17), este efecto puede ser atribuible a la naturaleza porosa, grietas y menor resistencia del mortero adherido (18).
In accordance with other experiences (9-12), the recycled aggregates studied were non-plastic, and their form coefficients, crushed particles and sand equivalents fulfill the limits set by standard. The form coefficient in RCA and NA is similar and smaller than MD.

The RCA had higher sand equivalents than the MD and $N A$, except $M D-3$. There is a relationship between proportions of natural aggregates with mortar attached (concrete \& mortar) and sand equivalent: the higher amount of concrete, the higher sand equivalent is.

The clean coefficient is not a critical property; all recycled aggregates satisfy the limits established by standard (Art. 510 in PG-3), except MD-4, this may be related to the higher percentage of fines particles. Los Angeles coefficient depends mainly from the abrasion suffered by the natural aggregate, concrete and ceramic materials. Recent studies have related that in Los Angeles abrasion test all the attached mortar of recycled concrete aggregate is powdered (17) this effect can be attributable to the porous nature, cracks and less strength of the attached mortar (18). 
Los áridos reciclados de hormigón (RCA) ensayados tienen un coeficiente de Los Ángeles más bajo del 35\% (33-34\%) cumpliendo el límite establecido para las categorías de tráfico T3 y T4. Sin embargo, en la literatura se encuentra una gran dispersión de resultados (17). Los valores del coeficiente de Los Ángeles obtenidos en este estudio para áridos reciclados de hormigón son ligeramente inferiores a los propuestos por otros autores: 37$38 \%$ (12), 32,9\% y $43,6 \%$ (19), $33,5 \%$ (20) y $39,65 \%$ (21). Estas diferencias pueden estar justificadas por la heterogeneidad de los áridos reciclados, la diferente cantidad de mortero adherido y la diferente abrasión sufrida por los áridos naturales.

Por el contrario, los áridos reciclados mixtos (MD) excepto el MD-4 superan el límite del coeficiente de Los Ángeles, obteniendo valores en torno al $40 \%$, la excepción (31\%) se debe probablemente a su mayor contenido en áridos naturales y asfalto. Los resultados son similares a los obtenidos por otros autores (12): 41-43\%. De acuerdo con esto, el coeficiente de Los Ángeles se identifica como una de las propiedades más limitantes de los áridos reciclados mixtos. El NA tiene el coeficiente de Los Ángeles más bajo (20\%).

Vegas y col. (12) también identifican que el contenido de compuestos de azufre totales es una propiedad crítica de los áridos reciclados. Sin embargo, el contenido de compuestos de azufre totales de los áridos reciclados de hormigón (fracción 0/2 mm) está por debajo del límite del PG3 (1\%). Pero todos los áridos reciclados mixtos contienen más del $1 \%$ de compuestos de azufre totales y el MD-4 el $6 \%$. Este alto contenido en el MD-4 en relación con los otros áridos reciclados mixtos puede estar justificado parcialmente por la mayor proporción de yeso en la fracción $8 / 40$ (Tabla 1 ) y por el proceso de tratamiento que no hace un precribado para eliminar la fracción fina (segunda planta de tratamiento), que generalmente contiene más cantidad de yeso responsable del alto contenido de compuestos de azufre totales de los áridos reciclados. El contenido de compuestos de azufre totales del NA es menor del 0,01\%.

Basado en los resultados de los ensayos de caracterización, los RCA estudiados cumplen con todas las especificaciones para ser usados en la construcción de sub-bases de carreteras para las categorías de tráfico T3 y T4. También, en los RCA el precribado de los RCD para eliminar la fracción fina no mejora sustancialmente los resultados con respecto al no precribado de los RCD (RCA-1 vs. RCA-2 y RCA-3). Sin embargo, el precribado de la fracción fina de los RCD en las plantas de reciclaje es fundamental para reducir el contenido de compuestos totales de azufre de los áridos reciclados mixtos y aumentar su calidad.

Sherwood (22) propone que en carreteras de bajo coste y volumen de tráfico, la reducción razonada de los requisitos
The recycled concrete aggregates ( $R C A$ ) tested have a Los Angeles coefficient lower than 35\% (33-34\%) fulfill the limit established for traffic categories T3 and T4. However, a great dispersion of results can be observed in the literature (17). Los Angeles coefficients obtained in this study for recycled concrete aggregates are slightly lower than those proposed by other authors: $37-38 \%$ (12), 32.9\% and $43.6 \%$ (19), 33.5\% (20) and $39.65 \%$ (21). These differences can be justified by the heterogeneity of recycled aggregates, different content mortar attached and different abrasion suffered by the natural aggregates.

By contrast, the recycled aggregates from mixed debris (MD) except MD-4 exceed the limit of Los Angeles coefficient, obtaining values of around $40 \%$, the exception (31\%) being probably due to its increased content in natural aggregates and asphalt. The results are similar to those obtained by another authors (12): $41-43 \%$. According with this, Los Angeles coefficient is identified as one of the most critical properties of recycled aggregates from mixed debris. The NA has a Los Angeles coefficient lowest (20\%).

Vegas et al. (12) also identified that the total sulphur compounds is a critical property of recycled aggregates. However, the contents in total sulphur compounds of the recycled concrete aggregates (fractions $0 / 2 \mathrm{~mm}$ ) were all below the PG-3 limit (1\%). But all mixed aggregates contained more than $1 \%$ sulphur compounds and MD-4 as much as $6 \%$. Such a high content in MD-4 relative to the other mixed recycled aggregates can be justified partially by the highest proportion of gypsum in the fraction $8 / 40$ (Table 1) and by the treatment process involving no pre-screening to remove the fine fraction (second recycling plant), which usually contains abundant gypsum and is responsible the high total sulphur content of recycled aggregates. The total sulphur compounds of NA were less than $0.01 \%$.

Based on the results of the characterization tests, the RCA studied comply with all the specifications for use in sub-bases roads constructions in traffic categories T3 and T4. Also, in RCA pre-screening CDW to remove the fine fraction results in no substantial improvement with respect to not pre-screening CDW (RCA-1 vs. RCA-2 and $R C A-3)$. However, pre-screening the fine fraction of CDW reaching a recycling plant is crucial with a view to reducing the total sulphur content of mixed debris and raising their quality.

Sherwood (22) proposed that, in low cost and volume roads, judicious relaxation of the requirements in the 
de las normas nacionales podría aumentar el uso de materiales secundarios. Así, aunque los áridos reciclados mixtos MD-1 y MD-2 no cumplan con el coeficiente de Los Ángeles y el contenido de compuestos de azufre totales por un estrecho margen, podrían ser utilizados como sub-base en la construcción de caminos rurales.

\subsection{Relación entre humedad y densidad}

La Figura 2 muestra las curvas que relacionan la humedad y la densidad seca obtenidas del ensayo Proctor modificado. Los RCA y NA con curvas más pronunciadas son más sensibles a los cambios en el contenido de humedad que los MD con curvas más planas. En línea con otras investigaciones internacionales la densidad seca alcanzable en el ensayo Proctor es bastante insensible al contenido de humedad en los MD (23), no obstante, su humedad óptima y densidad seca máxima están recogidas en la Tabla 5 . national specifications might boost the use of partially compliant secondary materials. Thus, although our mixed aggregates $M D-1$ and MD-2 failed to comply with the Los Angeles loss and total sulphur content specifications by a narrow margin, they might be useful as unbound road sub-base in rural road construction.

\subsection{Moisture-density relationship}

Figure 2 shows the relationship between moisture and dry density curves obtained from the Modified Proctor test. RCA and NA with sharp curves were more sensitive to changes in moisture content than were the MD with flat curves. In the line with other international research the dry density achievable in the Proctor test is rather insensitive to the moisture content in MD (23), nevertheless their optimum moisture contents and the corresponding maximum dry densities are summarized in Table 5.

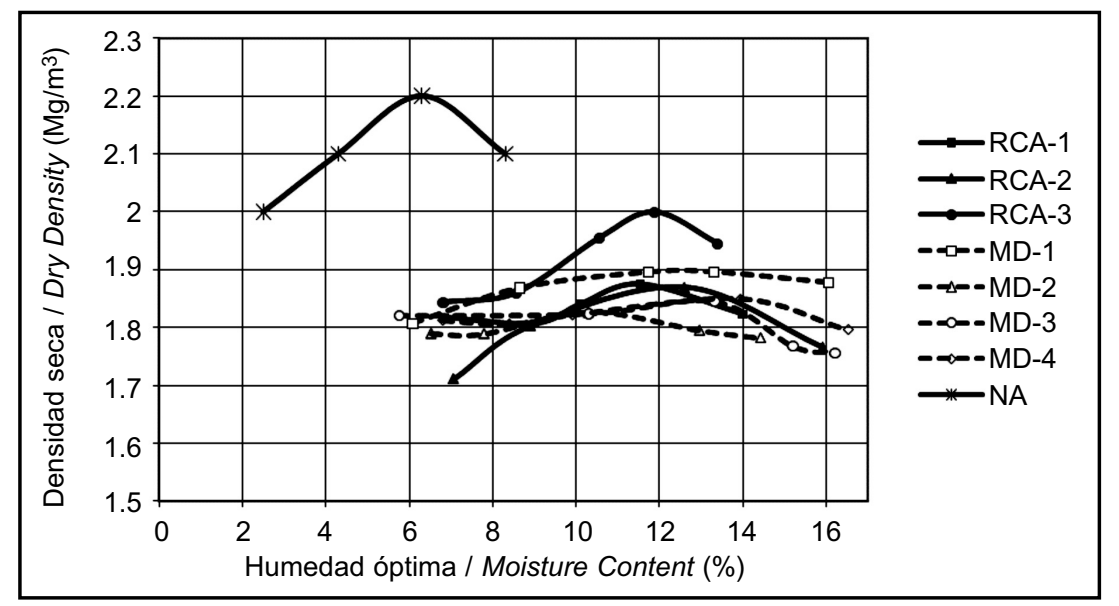

Figura 2. Relación entre humedad y densidad seca. Figure 2. Moisture-density relationship.

Tabla 5 / Table 5

Humedad óptima y densidad seca máxima: ensayo Proctor Modificado. Optimum moisture content and maximum dry density: Modified Proctor test.

\begin{tabular}{|c|c|c|}
\hline Tipo de árido / Aggregate type & $\begin{array}{c}\text { Humedad óptima / } \\
\text { Optimum moisture content (\%) }\end{array}$ & $\begin{array}{c}\text { Densidad seca máxima / } \\
\text { Maximum dry density (Mg/m } \mathbf{m}^{\mathbf{3}} \text { ) }\end{array}$ \\
\hline NA & 6.30 & 2.21 \\
\hline RCA-1 & 11.6 & 1.88 \\
\hline RCA-2 & 12.6 & 1.87 \\
\hline RCA-3 & 11.7 & 2.00 \\
\hline MD-1 & 12.7 & 1.91 \\
\hline MD-2 & 10.3 & 1.83 \\
\hline MD-3 & 13.3 & 1.85 \\
\hline MD-4 & 13.0 & 1.83 \\
\hline
\end{tabular}

La diferencia entre la densidad seca máxima y la humedad óptima se debe principalmente a la diferencia entre la densidad y capacidad de absorción de agua de los materiales (13). La densidad de partículas tras secado en
The difference in the maximum dry density and the optimum moisture content was mainly caused by the difference in the density and the water absorption capacity of materials (13). The density-oven-dry and the 
estufa y la capacidad de absorción de agua de la fracción gruesa y fina aparecen en la Tabla 6. En los RCA y NA la densidad de las partículas tras secado en estufa de la fracción gruesa es mayor que en la fracción fina, mientras que en los MD la densidad de la fracción fina es similar a la gruesa. En los RCA y NA la capacidad de absorción de agua de la fracción fina es mayor que el de la fracción gruesa mientras en los MD no hay diferencias significativas. water absorption of coarse and fine fraction are summarized in Table 6. In RCA and NA the density-ovendry of coarse fraction is higher than fine fraction while in $M D$ the fine fraction is similar to coarse fraction. In RCA and NA the water absorption capacity of fine fraction is higher than coarse fraction while in MD no significant differences are.

Tabla 6 / Table 6

Densidad de las partículas tras secado y absorción de agua. Density-oven-dry and water absorption.

\begin{tabular}{|c|c|c|c|c|}
\hline \multirow{2}{*}{ Aggregate size } & \multicolumn{2}{|c|}{$\begin{array}{c}\text { Densidad de las partículas tras secado / } \\
\text { Density-oven-dry } \mathbf{( k g / \mathbf { m } ^ { 3 } )}\end{array}$} & \multicolumn{2}{c|}{ Absorción de agua / Water absorption (\%) } \\
\cline { 2 - 5 } & $\mathbf{0 . 0 6 3 / 4} \mathbf{~ m m}$ & $\mathbf{4} \mathbf{3 1 . 5} \mathbf{~ m m}$ & $\mathbf{0 . 0 6 3 / 4} \mathbf{~ m m}$ & $\mathbf{4 / 3 1 . 5} \mathbf{~ m m}$ \\
\hline NA & 2399 & 2590 & 4.7 & 1.6 \\
\hline RCA-1 & 2138 & 2243 & 8.8 & 6.7 \\
\hline RCA-2 & 2061 & 2313 & 9.6 & 5.3 \\
\hline RCA-3 & 2369 & 2435 & 9.4 & 3.7 \\
\hline MD-1 & 2154 & 2116 & 8.5 & 8.3 \\
\hline MD-2 & 2135 & 2156 & 9.4 & 8.1 \\
\hline MD-3 & 2198 & 2175 & 8.1 & 8.5 \\
\hline
\end{tabular}

De acuerdo con la bibliografía, el árido natural de control tiene la mayor densidad de partículas y el porcentaje de absorción de agua más bajo y presenta el valor más alto de densidad seca máxima y el menor valor de humedad óptima en el ensayo Proctor modificado. Mientras que la diferencia en la densidad seca máxima y la humedad óptima entre los áridos RCA y MD fue pequeña (viz. 1,92 $\mathrm{Mg} / \mathrm{m}^{3}$ vs $1,85 \mathrm{Mg} / \mathrm{m}^{3}$ como media en la densidad seca y $11,97 \%$ vs $12,32 \%$ en la humedad óptima).

\subsection{California bearing ratio}

Los áridos reciclados fueron compactados a la humedad óptima (Tabla 5) y sometidos al ensayo de California bearing ratio (CBR) bajo condiciones de 4 días de inundación y usando una sobrecarga de 4,5 kg.

Basándose en los resultados del ensayo (Tabla 4), todos los áridos reciclados ensayados tienen una alta capacidad de carga, coincidiendo con los resultados de otros autores $(8,9)$. El NA mostró el valor más alto de CBR $(152 \%)$, y los RCA tienen un valor mayor (97-138\%) que los MD (62-94\%), probablemente debido a la menor resistencia de las partículas de hormigón y cerámicas.

El hinchamiento después de 4 días de inundación fue inferior al 0,06\%, lo que puede considerarse insignificante para los ocho materiales ensayados, lo que garantiza la estabilidad de las capas estructurales.
According with the literature, the control natural aggregate had the highest particle density and the lowest water absorption and had the highest maximum dry density and the lowest optimum moisture content in Modified Proctor test. While the difference in the maximum dry density and the optimum moisture content between RCA and MD aggregates was small (viz. 1.92 $\mathrm{Mg} / \mathrm{m}^{3}$ vs $1.85 \mathrm{Mg} / \mathrm{m}^{3}$ as average in dry density and $11.97 \%$ vs $12.32 \%$ in optimum moisture content).

\subsection{California bearing ratio}

The recycled aggregates were compacted at their respective optimum moisture contents (Table 5) and subjected to the California bearing ratio (CBR) test under soaking conditions for 4 days, using a total overload of $4.5 \mathrm{~kg}$.

Based on the results of test (Table 4), all recycled aggregates tested have a high bearing capacity, consistent with previous results $(8,9)$. NA had the highest CBR values (152\%), and RCA had higher CBR values $(97-138 \%)$ than MD (62 - 94\%) probably due to the lower intrinsic particle strength of concrete and ceramics.

Swelling after 4 days of soaking was less than $0.06 \%$ which can be considered negligible, ensuring the stability of the structural layer of eight materials tested. 


\section{CONCLUSIONES}

El presente trabajo muestra una evaluación técnica de tres áridos reciclados de hormigón (RCA) y cuatro áridos reciclados mixtos (MD), procedentes de tres plantas de tratamiento con diferentes procesos de reciclado situadas en Córdoba (España), como material para la construcción de sub-bases de carreteras. Los resultados se comparan con un árido natural de control. Las principales conclusiones se detallan a continuación:

1. El árido natural presenta las mejores propiedades, seguido de los áridos reciclados de hormigón y los mixtos.

2. Los áridos reciclados de hormigón ensayados cumplen los límites establecidos en el Pliego de Prescripciones Técnicas Generales para Obras de Carreteras (PG-3) para capas granulares estructurales (subbase) en las categorías de tráfico T3 y T4.

3. Los áridos reciclados mixtos no cumplen algunas especificaciones de la norma mencionada anteriormente. Las propiedades críticas para el uso de los áridos reciclados mixtos en la construcción de capas estructurales (sub-base) son el contenido de compuestos de azufre totales y el coeficiente de Los Ángeles. Además, uno de estos materiales no cumple con las especificaciones para el coeficiente de limpieza.

4. En el proceso de reciclaje de residuos de hormigón no es necesario el pre-cribado para eliminar la fracción fina; las propiedades del RCA-1 (pre-cribado) son similares a las del RCA-2 y RCA-3 (no pre-cribados).

5. En cambio, en el proceso de reciclaje de escombros mixtos el pre-cribado para eliminar la fracción fina reduce el contenido de compuestos de azufre totales en el árido reciclado (MD-1, MD-2 y MD-3) y mejora su calidad.

6. El árido natural tiene la mayor densidad seca y la menor absorción de agua. Los áridos reciclados de hormigón tienen una mayor densidad seca y menor absorción de agua que los mixtos. En los áridos reciclados de hormigón y en el árido natural, la densidad de partículas tras secado en estufa de la fracción gruesa es mayor que la de la fracción fina, mientras que en los mixtos ambas densidades son similares. En los áridos reciclados de hormigón y el árido natural la absorción de agua de la fracción fina es superior a la de la fracción gruesa, mientras que en los mixtos no se aprecian diferencias significativas.

7. En el ensayo Proctor modificado el árido natural tiene una mayor densidad seca máxima y menor contenido de humedad óptima que los áridos reciclados de hormigón y mixtos. El árido natural y los áridos reciclados de hormigón son más sensibles a los cambios en el contenido de humedad que los áridos reciclados mixtos.

8. El árido natural tiene el mayor valor de CBR, seguido de los áridos reciclados de hormigón y de los mixtos. Basándose en el alto valor del CBR y en la ausencia

\section{CONCLUSIONS}

This paper present a technical assessment of three recycled concrete aggregates (RCA) and four recycled aggregates from mixed debris (MD) collected from three different centralized processing plants with different recycling process located in Córdoba (Spain) as material for unbound road sub-bases construction The results were compared with a natural aggregate as control. The main conclusions are set out below:

1. Natural aggregate had the best properties, followed by recycled concrete aggregates and mixed debris.

2. Recycled concrete aggregates tested satisfies the limits established in the Spanish General Technical Specifications for Road Construction (PG-3) as material for road granular structural layers (subbase) in traffic categories T3 and T4.

3. Mixed debris didn't satisfy some specifications in the above-mentioned regulation. The critical properties for using mixed debris in the construction of structural unbound layers (sub-base) are the Los Angeles coefficient and total sulphur content. Also, one of the mixed debris was incompliant with the specifications for the clean coefficient.

4. In the recycling process of concrete waste the prescreening to remove the fine fraction isn't needed; the properties of RCA-1 (pre-screened) are similar to RCA-2 and RCA-3 (no pre-screened).

5. By contrast in the recycling process of mixed debris the pre-screening in order to remove the fine fraction reduces the total sulphur content in the recycled aggregate (MD-1, MD-2 and MD-3) and improves its quality.

6. Natural aggregate had the highest density-oven-dry and lowest water absorption. The recycled concrete aggregates had higher density-oven-dry and lower water absorption than mixed debris. In recycled concrete aggregates and natural aggregate the density oven-dry of coarse fractions is higher tan fine fraction while in mixed debris the fine fraction is similar to coarse fraction. In recycled concrete aggregates and natural aggregate the water absorption capacity of fine fraction is higher than coarse fraction while in mixed debris no significant differences are.

7. In modified Proctor test natural aggregate had a higher dry density and lower optimum moisture content than did the recycled concrete aggregates and mixed debris. Natural aggregate and recycled concrete aggregates were more sensitive to changes in moisture content than were the mixed debris.

8. Natural aggregate has the best CBR value, followed by recycled concrete aggregates and mixed debris. Based on the high CBR value and the absence of 
de hinchamiento tanto en los áridos reciclados de hormigón como en los mixtos, se puede esperar que ambos posean una aceptable capacidad de carga y estabilidad estructural.

9. Si las plantas de tratamiento de residuos de construcción y demolición mantienen un buen control de calidad del material reciclado, este se podrá utilizar directamente como sub-base en el firme de carreteras. Sin embargo los ingenieros y se muestran aún reticentes a utilizar estos materiales. Por lo tanto, los ensayos de caracterización y de comportamiento realizados en este estudio deben complementarse con ensayos en tramos de prueba de carreteras, para evaluar su uso potencial y superar la desconfianza existente.

\section{AGRADECIMIENTOS}

Los autores agradecen a la Empresa Pública EPREMASA, S.A. por financiar parte de esta investigación. swelling in both recycled concrete aggregates and mixed debris, the two types of recycled material can be expected to possess an acceptable bearing capacity and structural stability.

9. If the constructions and demolitions waste processing plants keep good quality control of the recycled material will be ready to be directly used as sub-base road pavement. Nevertheless engineers are still reluctant to adopt this recycled product. Therefore, the characterization and performance tests conducted in this study could be supplemented with assays in road test sections, to evaluate their potential use and overcome the existing mistrust.

\section{ACKNOWLEDGEMENTS}

The authors thank the Public Company EPREMASA S.A. for funding part of this research.

\section{BIBLIOGRAFÍA / BIBLIOGRAPHY}

(1) Tam, V. W.; Tam, C.M.: "Evaluations of existing waste recycling methods: A Hong Kong study", Building and Environment, 41 (2006), pp. 1649-1660. doi:10.1016/j.buildenv.2005.06.017

(2) Ministerio de Medio Ambiente, y Medio Rural y Marino: "Plan Nacional Integrado de Residuos para el periodo 2008-2015", BOE, no 49 (2009), pp. 19893-20016.

(3) Ministerio de Fomento: "Orden/FOM/891 por la que se actualizan determinados artículos del Pliego de Prescripciones Técnicas Generales para Obras de Carreteras y Puentes, relativos a firmes y pavimentos", BOE, no 83 (2004), pp. 14446-14509.

(4) Comisión 2. Grupo de Trabajo 2/5: Monografía M-11 Utilización de árido reciclado para la fabricación de hormigón estructural. ACHE, Madrid (2006).

(5) Ministerio de Fomento: "Instrucción de Hormigón Estructural (EHE-08)", BOE, no 203, Suplemento (2008), pp. 1-304.

(6) Ministerio de la Presidencia: "RD 105/2008 por el que se regula la producción y gestión de los residuos de construcción y demolición", BOE, no 38 (2008), pp. 7724-7730.

(7) Solis Guzmán, J.; Marrero, M.; Montes-Delgado, M. V.; Ramírez-de-Arellano, A.: "A Spanish model for quantification and management of construction waste", Waste Manag., 29 (2009), pp. 2542-2548. doi:10.1016/j.wasman.2009.05.009 mn PMid:19523801

(8) Tertre, J. I.: "Gestión de residuos de construcción y demoliciones", Informes de la Construcción, vol. 59, 506 (2007), pp. 131-135.

(9) Jiménez, J. R.; Agrela, F.; López, M.; Ayuso, J.; González, A.: "Caracterización y posibilidades de reutilización en obras de infraestructuras de los RCD procedentes de la prisión provincial de Córdoba", III Congreso de Ingeniería Civil, Territorio y Medio Ambiente, Zaragoza, 2006, p. 231.

(10) Agrela, F.; Jiménez, J. R.; López, M.; Ayuso, J.; Caballero, A.: "Caracterización y posibilidades de reutilización en obras de infraestructuras de los RCD sin selección en origen y procedentes de todas las tipologías de obras", III Congreso de Ingeniería Civil, Territorio y Medio Ambiente, Zaragoza, 2006, p. 231.

(11) Jiménez, J. R.; Agrela, F.; López, M.; Ayuso, J.; González, A.; González, J.: "Estudio de las posibilidades de reutilización de RCD en rellenos tipo terraplén y explanadas", IV Congreso Andaluz de Carreteras, tomo 2, Jaén, 2007, pp. 1503-1516.

(12) Vegas, I.; Ibáñez, J. A.; San José, J. T.; Urzelai, A.: "Construction demolition wastes, Waelz slag and MSWI bottom ash: A comparative technical analysis as material for road construction", Waste Management, 28 (2008), pp. 565-574. doi:10.1016/j.wasman.2007.01.016 PMid:17451930

(13) Poon, C. S.; Chan, D.: "Feasible use of recycled concrete aggregates and crushed clay brick as unbound road sub-base", Construction and Building Material, 20 (2006), pp. 578-585. doi:10.1016/j.conbuildmat.2005.01.045

(14) Arm, M.: "Self-cementing properties of crush demolished concrete in unbound layers: results from triaxial test and field test", Waste Management, 21 (2001), pp. 235-239. doi:10.1016/S0956-053X(00)00095-7

(15) Tam, V. W.; Tam, C. M.: "Crushed aggregate production from centralized combined and individual waste sources in Hong Kong", Construction and Building Material, 21 (2007), pp. 879-886. doi:10.1016/j.conbuildmat.2005.12.016

(16) Weibull, W.: "A statistical distribution function of wide applicability", J. Appl Mech, 18 (1951), pp. 293-297. 
(17) Sanchez, M.; Alaejos, P.: "Study on the influence of attached mortar content on the properties of recycled concrete aggregate", Construction and Building Material, 23 (2009), pp. 872-877. doi:10.1016/j.conbuildmat.2008.04.012

(18) Tam, V. W.; Gao, X. F.; Tam, C. M.: "Microstructural analysis of recycled aggregate concrete produced from two-stage mixing approach", Cement and Concrete Research, 35 (2005), pp. 1195-1203. doi:10.1016/j.cemconres.2004.10.025

(19) Park, T.: "Application of construction and building debris as base and subbase materials in rigid pavement", Journal of Transportation Engineering ASCE/September/October (2003), pp. 558-563. doi:10.1061/(ASCE)0733-947X(2003)129:5(558)

(20) Etxeberria, M.; Marí, A. R.; Vázquez, E.: "Recycled aggregate concrete as structural material", Materials and Structures, no 40 (2007), pp. 529-541. DOI 10.1617/s11527-006-9161-5 doi:10.1617/s11527-006-9161-5

(21) Pére, I.; Toledano, M.; Gallego, J.; Taibo, J.: "Mechanical properties of hot mix asphalt made with recycled aggregates from reclaimed construction and demolition debris", Mater. Construcc., vol. 57, no 285 (2007), pp. 17-29.

(22) Sherwood, P. T.: Alternative materials in road construction, Thomas Telford, London (2001).

(23) Molenaar, A. A.; Van Niekerk A. A.:. "Effects of gradation, composition, and degree of compaction on the mechanical characteristics of recycled unbound materials", Transportat Res Rec, nº 1787 (2002), pp. 73-82. 